\title{
Green Marketing Practices of Manufacturers in Virudhunagar District
}

\author{
G. Ramesh Pandi
}

\begin{abstract}
Eco-care has rapidly come out as a worldwide happening. Marketers have risen to the circumstance and have started reacting to ecological confronts by practicing eco-care marketing approach. The alertness of the Eco-friendly buying and selling activities are maximized among the Indian consumers. Many of the producers are keeping touch with Green marketing practices in India. So, the Green marketing thought is not the new survival mantra of the business units.

Eco-friendly has added thrust in the perspective of global warming and weather change; they have forced producers to integrate the principle of eco-friendly buying and selling processes. As resources are minimized and individual wants are maximized, resources have to be used reasonably and in an eco-friendly mode. Therefore, it is necessary for the manufacturers to reconsider their business strategy to make the manufacturing process as eco-friendly way. With this back draft, the researcher makes an attempt to analyze the practices of manufacturers regard with green marketing in Virudhunagar District of Tamil nadu. For that purpose, the factor analysis has been applied and the inference was made.
\end{abstract}

Keywords: Green Marketing Practices, Green Environment, Waste Management

\section{INTRODUCTION}

Eco-friendly marketing focus the meaning of planning, development of eco- friendly goods or services to fulfill the necessities of final buyers with quality, quantity, finest price and service, without having a harmful outcome on the usage or its users. Therefore, eco-friendly buying and selling process refers to a holistic marketing design in which the manufacturing, marketing, consumption and disposal of goods and services happen in a way with less harmful to the surroundings by increasing consciousness about the impact of global warming, non- biodegradable solid waste and detrimental force of pollution. It is a truth that both buyers and sellers are more and more aware on the need to change over eco-friendly goods and services. The progress from the existing buying and selling methods to eco-friendly buying and selling process may be shown to be costly in the tiny period, but it will extremely confirm to be vital, useful and minimum cost value in the long run. (Sandhya Joshi, 2011).

Eco-friendly buying and selling process is rapidly varying the trendy marketing approaches as per the buyer requirement in a sustainable mode.

Revised Manuscript Received on December 16, 2019

* G. Ramesh Pandi, Associate Professor, Department of Commerce, Kalasalingam Academy of Research and Education, Krishnan Koil, Virudhunagar District, India.

E-mail id: g.ramesh.jith@gmail.com
Eco-friendly buying and selling strategy obtains numerous advantages like maximization of income, reduction of expenses, new goods expansion, risk mitigation, environment defense, global security and improved brand status. Eco-friendly buying and selling process is wanted to deal with environmental problems which affect all human being society and natural atmosphere. (Divesh Kumar et al., 2011).

A lot of manufacturers would like to shift green, as a rising number of customers and to connect them with eco- friendly goods. In particular, one often finds the concerning of trustworthiness of eco-goods.

Therefore, to confirm the shopper self-assurance, manufactures of eco-friendly goods require being much more crystal clear and desisting from violating any law or standards connected with the goods or business performance. (Chun-Shuo Chen \& Long-Yi Lin).

\section{LITERATURE REVIEW}

Azhagaiah, R and Ilangovan, A (2006) have analyzed that an environmental issue has a significant impact on modern society. At the same time, ecological condition is weakening at an alarming rate, mostly due to consumption-oriented buying and selling process. As a result, it will need a positive corporate buying and selling strategy and active government participation to promote eco-friendly buying and selling process. In addition, it must encourage re-consumption of goods through re-cycling of waste and enlarge the usage of capacity. Further, it must re-orient its marketing mix to expand and support eco-friendly, safe goods and re-organize it to reach the target.

The present ecology marketing wave depends on a better, more trustworthy and alerts eco-friendly marketing research activities as more. The eco-friendly marketing practice is carried out by manufacturers that expose themselves as being an Eco care taker. (Giorgia Nervi, 2008). Eco-friendly buying and selling process has enlarged its demand by controlling the negative effect of business activities on the environment. Competitive advantages can be reached with the practice of environmental related activities and encourages the corporate to go beyond mere legal fulfillment, So that competition itself might support more ecologically sustainable practices. (Ina Landua Glaciarvagen, 2008).

Eco-friendly buying and selling process is still in childhood stage and a lot of research needs to be done by the corporate to project an eco-friendly corporate likeness rather than focusing on the eco-friendly gaining. In future, only Eco friendly corporate will obtain the maximum incentive that innovates new goods, materials, technologies which are eco-centric and address the

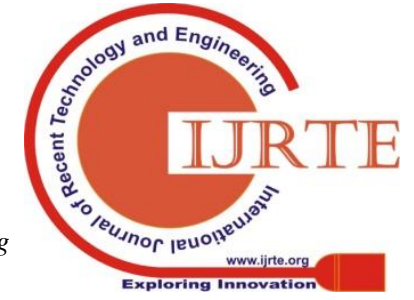




\section{Green Marketing Practices of Manufacturers in Virudhunagar District}

challenges by walking their talk. (Singh, P.B and Kamal K.Pandey, 2012)

Nai-Jen Chang and Cher-Min Fong (2010) have pointed out that the quality of eco-friendly goods could bring about eco-friendly shopper satisfaction and eco-friendly customer loyalty. Additionally, green corporate likeness gives eco-friendly customer fulfillment and the loyalty of eco-friendly customers. In the modern year, business moral values, social accountability, sustainable growth and environmental problems have become a key strategic concern among corporate. At the same time, consumers in most important international markets were challenging that corporate need to produce higher quality goods that are consistent with societal and environmental benefits if they wish to remain in the competitive global markets. Companies have developed and adopted green marketing strategies as a part of their corporate social responsibility

(CSR) strategies in order to meet the economic development of the area. At the same time, they also consider environmental protection. Thus, there is an interconnection between corporate social responsibility, sustainable development and green marketing activities and this will lead to green growth and will develop a green economy. (Susmitha Mohan and Philo Francis, 2014).

The reviews are collected under the title Green marketing Practices from various secondary sources. They provide a multilevel and multidisciplinary theoretical framework that synthesizes and integrates the literature. The authors' reviews highlight limited aspects of the sustainability practices of green marketing. Many of the authors are not studying the attitude of manufacturers towards green marketing practices thoroughly. Hence, the researcher has studied the green marketing practices of manufacturers and provided proper suggestions to uplift the sustainability green marketing practices in the market.

\section{THE RESEARCH PROBLEM}

The present situation strongly proofs that ecology issues appear to concern all civil societies, firms and organizations globally for the past two decades. There are brutal changes in the commercial world concerning the job towards the surroundings and the society. Strategies targeting not only make a profit for the day but also for long term prosperity and environment friendly sustainability have on track to become agendas of the companies. Another significant facet which a marketer wishes to deal with is to foresee the transformation which affects the future and consequently frame the marketing strategies.

Marketers today are confronted with environmental problems like global warming, green house release, contamination and energy disaster. Therefore, the sellers have to embrace a green move towards framing marketing strategies and are now required to go with eco-friendly process. It pressures that appropriate concern must be shown while framing the seller plans, strategies and policies so as to defend the surroundings and nature from any demolition caused due to its functions both at present and in future.

All the Corporate of the world are striving to diminish the negative impact of goods and services on the climate and other ecology source. So, in this situation of global concern, corporate houses have taken eco-friendly buying and selling process as a part of their tactics to endorse goods by employing ecological claims either about their qualities or about the schemes, policies.

Ecology buying and selling process is a part of overall corporate tactics; along with the workings of the traditional marketing mix (product, price, promotion and place). On the other hand, there is maximizing the attention among the consumers all over the world about the environmental safe. Worldwide data show that people are concerned about the surroundings and are changing their etiquettes. As a result of this, eco-care buying and selling activities have materialized and which are focused on about maximizing the market share of sustainable and socially responsible goods and services. In order to be familiar with the green marketing practices of producers in Virudhunagar District, this learning is carried out.

\section{METHODOLOGY}

This research depends on both the fresh and existing data. The fresh data are composed from the respondents through pretested interview schedules. There are totally 16,839 manufacturing units available in Virudhunagar District. It is impossible to gather the facts from the whole people. Therefore, it is determined to use sampling technique. Proportionate Stratified Random Sampling Technique has been applied to select the sample manufacturers

The Virudhunagar District has many industries and they are producing the products like food and beverages, textiles, wool, jute, wood and paper products, hosiery garments, leather and rubber products, chemical products, minerals, metals and machineries and miscellaneous products. Hence, the population is separated into eight groups according to the grouping of goods manufactured by them. Then the samples are selected proportionately from each stratum. The samples of $168(1 \%$ in 16,839) manufacturers are selected and explained with

Table- I Sample Design for Manufacturers

\begin{tabular}{|c|c|c|c|}
\hline S. No. & Category of the Industries & $\begin{array}{l}\text { Total number of } \\
\text { Population }\end{array}$ & Sample \\
\hline 1 & Food products and Beverages & 914 & 9 \\
\hline 2 & $\begin{array}{l}\text { Textiles ( cotton, jute, wool, } \\
\text { silk, and Hosiery garments) }\end{array}$ & 3663 & 37 \\
\hline 3 & Wood and Paper Products & 5206 & 52 \\
\hline 4 & $\begin{array}{l}\text { Leather and Rubber } \\
\text { Products }\end{array}$ & 773 & 8 \\
\hline 5 & $\begin{array}{l}\text { Chemicals ( Fireworks, } \\
\text { Match works and others }\end{array}$ & 3743 & 37 \\
\hline 6 & $\begin{array}{l}\text { Minerals, Metals and } \\
\text { Machineries }\end{array}$ & 1298 & 13 \\
\hline 7 & $\begin{array}{l}\text { Electricals, Transports } \\
\text { equipments }\end{array}$ & 535 & 5 \\
\hline \multirow[t]{2}{*}{8} & $\begin{array}{l}\text { Miscellaneous } \\
\text { Manufacturing units }\end{array}$ & 707 & 7 \\
\hline & Total & 16839 & 168 \\
\hline
\end{tabular}

Source: Industrial Profile of Virudhunagar District

2012-2013

Secondary data are

Published By:

Blue Eyes Intelligence Engineering \& Sciences Publication 
composed from standard text books connected to the theme, foremost journals, published reports and booklets, papers and records of the Government departments and the online sources. Facts processing and facts examination are carried out with help of Statistical Package for Social Sciences (SPSS) Version 16 by using suitable statistical techniques such as, Percentage Analysis and Factor Analysis. Percentage Analysis has been used to express the opinion of the respondents. In order to find out the factor affecting the attitude of manufacturers towards eco-care marketing practices, the researcher has applied the Factor Analysis.

\section{RESULTS AND DISCUSSION}

\section{A. Business Profile of the Manufacturers}

A business profile is necessary one to know the business background of the manufacturers. Because, business profile also may decides the environment of the business in an Eco friendly manner. So, the researcher has examined the business outline of the manufacturers such as kinds of business, kinds of ownership, Owners' business experience, business volume and net worth of the business. In case of types of business, Most of the producers (30.95\%) are making Paper and wooden goods in the study area; $38.10 \%$ are having partnership nature of business; During business experience, Most of the producers (25.00\%) are having five to ten years of business experience; $33.34 \%$ is invested Rs.50 lakhs to Rs. 1 crore in their business and Most of the producers $(32.74 \%)$ are having below Rs.50 lakhs as the net worth of business. B. Factors Affecting the Attitude of Manufacturers towards Green Marketing Practices: Application of Factor Analysis The attitudes of producers towards green marketing practices uniquely differ among the producers. During the survey, the producers have given their views about the green marketing practices. The view is obtained with the help of 43 statements which relate to the factors affecting the attitude of producers towards green marketing by applying the scaling technique, namely Likert Five Point Scale. The researcher has applied factor analysis. The result found that attempt taken for creating green environment, management of waste, Inducement for stabilizing green practices, controlling of Pollution, Proper maintenance and usage of goods, Monetary aid for protecting nature, Development of green region, Recycling of waste and keeping fit of green production methods are most influencing factors of the attitude of producers towards the green marketing practices.

By incorporating these factors in the best ratio, every producer should realize the need of the green manufacturing process and green marketing alone would save the living beings from extinction and it also helps to earn more earnings in future.

From this study, the researcher has found that the manufacturers face the difficulties in implementing the green marketing practices at their position. At the same time no one can neglect the importance of green marketing practices. If they are neglected, they have to pay a premium benefit in future. If the given suggestions are implemented, the Virudhunagar District gets good position.

\section{MANAGERIAL IMPLICATIONS}

- The Government may give financial aid or subsidy to manufacturers for importing green technologies which increase the green marketing practices among them and it can help to create foreign green manufacturers with our manufacturers to adopt green practices.

- The Government may follow strict regulations for waste management of biodegradable and non biodegradable wastes. It must be initiated through local governments like municipal corporations, panchayat unions and panchayat. All these local governments are asked to allocate the workers to collect both the wastes separately from each house, retail shops, factories and offices continuously. The wastes of non biodegradable goods must be sent to the recyclable industries for recycling them. Because, waste management is a part of green marketing practices.

- Manufacturers may broadcast many advertisements for their green products through various media like TV, News Paper and Online and so on. Because, many consumers opined that advertisement is the main promotion tool for getting information about green products. Particularly, they would like to watch TV channels because they are very convenient channels for them to receive matters regarding availability of green products, using methods etc., so, manufacturers may conduct more advertisements through TV channels by sponsoring various programmes.

- The researcher has suggested that the manufacturers should introduce some innovative methods in the production process like other countries techniques (Japanese 5S techniques, etc.,) to cut short the cost of green production. The initial investment cost of green technology is high, but it will give more green profit in the long run. Manufacturers should adopt new technology or process will lead to reduce the environmental impact.

- Manufacturers should utilize the more eco- friendly raw materials at the manufacturing stage itself and Manufacturers sought to discover probabilities of recycling of the used goods so that it can be used to offer same or other benefits with minimum wastages. "Effort taken for making green environment" is the main factor which influences the attitude of producers towards the green marketing practices of producers in Virudhunagar District. So, the researcher has suggested that the producers should plant a number of trees in the open places and roadsides of their factories and offices, using of LED bulbs, green star labeled air conditioners and other energy saving electronic appliances. Further, they are suggested to construct green buildings for expansion of their offices and factories, using of fuel saving vehicles for transport, giving training for staff and worker about green practices and using of the more online source for exchanging business matters, it reduces paper usage. These practices may support to

make their environment as clean. 


\section{REFERENCES}

1. R. Azhagaiah and A. Ilangovan, "Green Marketing and Environmental Protection,” Indian Journal of Marketing, Vol.36, No.1, pp.19-21, 2006.

2. Chun-Shuo Chen and Long-Yi Lin, A New Frame Work: Make Green Marketing Strategy Go With Competitive Strategy, Aletheia University: Taiwan.

3. Deepak Chawla and Neena Sondhi, Research Methodology Concepts and Cases, First edition., New Delhi: Vikas Publishing House Private Limited, 2014.

4. 4. Divesh Kumar., Ishwar Kumar., Ziller Rahman., Sresha Yadav and Praveen Goyal, "Green Marketing Mix; Rethinking competitive advantage during climate change,"ThefirstInternational Conference on Interdisciplinary Research and Development, Thailand, 2011.

5. Fred Karlinger, Methods of Factor Analysis Foundations of BehaviouralResearch, New York: Holt Richart and Winston Inc, 1973.

6. Giorgia Nervi, "Green Market Research Anyone? A Study on Green Market Research Practice among Companies," Department of Energy and Environment, Chalmers University of Technology, Goteborg, Sweden, 2008.

7. Ina Landua Glaciärvägen, "Gaining Competitive Advantage through Customer Satisfaction, Trust and Confidence in Consideration of the Influence of Green Marketing," University of Gavle, 2008.

8. Industrial Profile of Virudhunagar District 2012-2013, MSME Development Institute, Chennai, Ministry of MSME.

9. Nai-Jen Chang and Cher-Min Fong, "Green Product Quality, Green Corporate Image, Green Customer Satisfaction and Green Customer Loyalty," African Journal of Business Management, Vol.4, No.13, pp.2836-2844, 2010.

10. Sandhya Joshi, "Green Marketing: An Overview," International Journal of Science, Technology and Management, Vol.2, No.1, pp.36$41,2011$.

11. Singh, P.B., and Kamal K. Pandey, "Green marketing: Policies and Practices for Sustainable Development," Integral Review- A Journal of Management, Vol.5, No.1, pp.22-30, 2012.

12. Susmitha Mohan and Philo Francis, "Green Marketing: An initiative for Green growth," Facts for You, Vol.34, p-24, 2014.

\section{AUTHORS PROFILE}

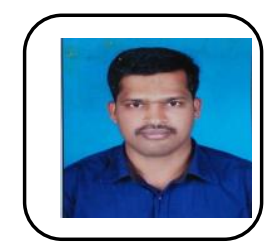

Dr. G. Ramesh Pandi M.Com, M.Phil., Ph.D SET, PGDCA, PGDPM. Author has published more than twenty two articles in the National and International level journals. One article published in the Scopus indexed journal. $\mathrm{He}$ is a member of Teaching and Education Research Association (TERA) and Social Science Research Association (SSHRA) of Eurasia Research. He has received Teaching Competency Award from Kalasalingam Academy of Research and Education (Deemed to be University), Virudhunagar District of Tamilnadu. He has presented sixty one research papers in the national and international level seminars and Conference organized by various Institutions. He has cleared three NPTEL courses. He acted as a chair person for various seminars, conferences and workshops. 